PAYMENTS FOR CARBON SEQUESTRATION TO ALLEVIATE DEVELOPMENT

PRESSURE

Running head: PAYMENTS FOR C SEQUESTRATION TO ALLEVIATE DEVELOPMENT PRESSURE

\title{
Payments for Carbon Sequestration to Alleviate Development Pressure in a Rapidly Urbanizing Region
}

\author{
Jordan W. Smith \\ Utah State University \\ Monica A. Dorning \\ US Geological Survey \\ Douglas A. Shoemaker, Andréanne Méley \\ NC State University \\ Lauren Nicole Dupéy \\ Utah State University \\ Ross K. Meentemeyer \\ NC State University
}

\begin{abstract}
Author Note
Jordan W. Smith and Lauren Nicole Dupéy, Department of Environment and Society, Utah State University; Monica A. Dorning, US Geological Survey; Douglas A. Shoemaker, Andréanne Méley, and Ross K. Meentemeyer, Center for Geospatial Analytics, NC State University.
\end{abstract}

This research was supported by a grant from the National Science Foundation (\#0949170) and support from the College of Natural Resources at NC State University. The authors would like to acknowledge Georgina M. Sanchez for creating Figure 1.

Corresponding author: Jordan W. Smith, Department of Environment and Society, Utah State University, Logan, UT 84322. E-mail: green.olympia@ gmail.com 


\begin{abstract}
The purpose of this study was to determine individuals' willingness to enroll in voluntary payments for carbon sequestration programs through the use of a discrete choice experiment delivered to forest owners living in the rapidly urbanizing region surrounding Charlotte, North Carolina. We examined forest owners' willingness to enroll in payments for carbon sequestration policies under different levels of financial incentives (annual revenue), different contract lengths and different program administrators (e.g., private companies versus a state or federal agency). We also examined the influence forest owners' sense of place had on their willingness to enroll in hypothetical programs. Our results showed a high level of ambivalence towards participating in payments for carbon sequestration programs. However, both financial incentives and contract lengths significantly influenced forest owners' intent to enroll. Neither program administration nor forest owners' sense of place influenced intent to enroll. While our analyses indicated payments from carbon sequestration programs are not currently competitive with the monetary returns expected from timber harvest or property sales, certain forest owners might see payments for carbon sequestration programs as a viable option for offsetting increasing tax costs as development encroaches and property values rise.
\end{abstract}

Keywords: stated choice methods; urbanization; payments for ecosystem services 


\section{Payments for Carbon Sequestration to Alleviate Development Pressure} in a Rapidly Urbanizing Region

\section{Introduction}

Across the United States, forest and agricultural landscapes are becoming increasingly

6 fragmented as urban populations grow and cities expand (Theobald 2005; Theobald 2001;

7 Theobald and Romme 2007). The fragmentation of urban-proximate forest and agricultural

8 landscapes can have both immediate and long-term effects on natural systems. Immediate

9 impacts include the displacement of wildlife as habitat degrades as well as reductions in water

10 quality as erosion increases due to the direct removal of above-ground biomass (Hansen et al.

11 2005; Paul and Meyer 2001). The long-term environmental impacts of urban-proximate

12 landscape fragmentation are more difficult to observe. The loss of endemic plant and animal

13 species as well as biological diversity more generally, may only be realized after urbanization is

14 well underway (Theobald, Miller, and Hobbs 1997). Similarly, alterations to natural or semi-

15 natural hydrologic systems (primarily as a result of increased water use) may impact the ability

16 of ecological systems to respond to drought and climate-related stressors (Allan 2004). In

17 response to these direct impacts and long-term feedbacks, urban planners, forest managers and

18 agricultural associations are actively seeking out and exploring viable policies and programs that

19 conserve forest and agricultural landscapes and maintain the ecosystem services they provide

20 (Gobster, Stewart, and Bengston 2004).

21 Payments for ecosystem services policies are one of many potential policy options to

22 slow the rate of land use conversion in urbanizing areas (Bengston, Fletcher, and Nelson 2004;

23 Salzman 2005). Payments for ecosystem services can provide non-industrial private forest

24 owners a financial incentive to conserve or manage their land for the production of a valued 
25 ecosystem service like sequestering carbon from the atmosphere, maintaining water quality or

26 conserving wildlife habitat (Jack, Kousky, and Sims 2008; Engel, Pagiola, and Wunder 2008).

27 Simply put, payments for ecosystem services programs are policy instruments which require

28 individuals (typically landowners) to engage in a specific land management practice that: 1)

29 comes at a personal cost (which can include opportunity costs); and 2) results in the continued or

30 enhanced production of an ecological service that benefits society (Shelley 2011). As a note, we

31 use the terminology 'payments for ecosystem services' given it connotes the Millennium

32 Ecosystem Assessment's simple definition of 'ecosystem services' as 'the benefits people obtain

33 from ecosystems" (2003, 3). Interested readers are referred to Shelley (2011) and Derissen and

34 Latacz-Lohmann (2013) for substantive reviews of the terminology used to describe these types

35 of policy instruments.

36 Payments for carbon sequestration policies are particularly attractive mechanisms

37 because they often do not require intensive investments of either time or money from the forest

38 owner, allowing the forest owner to benefit financially from non-intensive management

39 strategies (Bigsby 2009; Lippke and Perez-Garcia 2008). Payments for carbon sequestration

40 policies may be especially appealing in the United States where most non-industrial private

41 forest owners do not actively manage their property through a forest management plan. Just $4 \%$

42 of non-industrial private forest owners in the United States have a written management plan and

43 only $14 \%$ have ever sought out professional advice about their woodlands (Butler 2008). Other

44 potential policy solutions such as cost-share programs have not been widely adopted, presumably

45 because they are designed to supplement the forest products industry and often stipulate forest

46 owners actively manage their woodlands for timber extraction (Kilgore et al. 2007); only 6\% of 
47 non-industrial private forest owners in the United States have ever participated in a cost-share 48 program (Butler 2008).

Aside from the appeal of not being directly tied to the forest products industry, payments

50 for carbon sequestration policies might also be attractive to forest owners because they align

51 directly with non-timber values (Bengston, Asah, and Butler 2010). Over the past 45 years, the

52 nonuse and noneconomic values private forest owners' ascribe to their woodlands have become

53 stronger (Bengston, Asah, and Butler 2010). Urban residents in particular, tend to hold the

54 strongest nonuse forest values (Tarrant, Cordell, and Green 2003). Additionally, the average age

55 of the non-industrial private forest owner in the United States is declining as older forest owners

56 either sell their properties for development or transfer them to their children (Butler 2008). The

57 growing body of research on the shifting values of non-industrial private forest owners suggests

58 younger generations who inherit land have very strong psychological attachments to their

59 properties (Bliss and Martin 1989; Creighton, Blatner, and Carroll 2015; Gordon, Barton, and

60 Adams 2013; BenDor et al. 2014). The strong meanings forest owners tie to their properties is

61 likely an important factor affecting decisions about how they manage their land. Logically, the

62 stronger the psychological meanings a forest owner has towards their woodlands, the less likely

63 they would be to sell; conversely, the more likely they would be to enroll in a program allowing

64 them to manage their land in a low-intensity yet financially-beneficial way.

\section{Aim and Objectives}

Despite the anticipated benefits associated with payments for carbon sequestration

67 policies, only a few studies have explicitly examined the willingness of forest owners in

68 urbanizing regions to enroll in voluntary payments for carbon sequestration programs (Fletcher,

69 Kittredge, and Stevens 2009; Dickinson et al. 2012; Markowski-Lindsay et al. 2011). Recent 
70 related research has been conducted on forest owners' attitudes towards carbon sequestration

71 programs (Khanal et al. 2016). In this study we explored individuals' willingness to enroll in a

72 voluntary payments for carbon sequestration program through the use of a discrete choice

73 experiment delivered to non-industrial private forest owners living in the rapidly urbanizing

74 region surrounding Charlotte, North Carolina (USA). Specifically, we examined forest owners'

75 willingness to adopt payments for carbon sequestration policies that varied in their financial

76 incentives (i.e., annual payments), contract length requirements and type of administration (e.g.,

77 private companies versus a state or federal agency). Given payments for carbon sequestration

78 programs may be more appealing to individuals who ascribe strong personal meanings to their

79 forestland, we also examined the influence forest owners' 'sense of place' has on their

80 willingness to enroll in a program. Our analysis was guided by four distinct hypotheses, each of

81 which is grounded in the literature, these are:

$82 \quad \mathrm{H}_{1}$ : Financial incentives will positively influence individuals' intent to enroll in payments

83 for carbon sequestration programs.

$84 \mathrm{H}_{2}$ : Contract length will negatively influence individuals' intent to enroll in payments for

$85 \quad$ carbon sequestration programs.

$86 \mathrm{H}_{3}$ : The type of organization (federal agency, state agency or a private company) administering a payments for carbon sequestration program, will not influence individuals' intent to enroll in payments for carbon sequestration programs. forested land and their intent to enroll in payments for carbon sequestration programs. 
In addition to explicitly testing these hypotheses, we used data collected from site visits

93 to respondents' properties to estimate those properties' development and timber value; these

94 values were compared against the financial returns that would be realized if the forest owner

95 were to enroll in the hypothetical programs described in the discrete choice experiment. Our

96 intent is to see how a hypothetical carbon market compares to current timber and development

97 markets that are driving land use conversion throughout the region.

Literature Review

99 Forest Owners' Intent to Enroll in Payments for Carbon Sequestration Programs

There is a growing body of research that has examined the willingness of private forest

101 owners to participate in payments for carbon sequestration programs using discrete choice

102 methods. Previous research has predominantly focused on the northern Atlantic and Midwestern

103 states (Table 1), we were unable to identify any research on the preferences for carbon

104 sequestration program attributes in the Southeastern United States.

carbon sequestration programs has assessed the relative influence of different program attributes

107 on willingness to participate. Fletcher et al. (2009) assessed the willingness of seventeen

108 Massachusetts private forest owners to sequester carbon on their forestland based on six

109 hypothetical programs. In their study, program attributes such as expected payment per acre $(\$ 5$,

$110 \$ 15$ or $\$ 30$ ), length of contract (5 or 10 years), penalty for early withdrawal and the requirement

111 to have a forest management plan in place were evaluated. The results suggested contract length,

112 expected payment per acre and early withdrawal penalties were significant determinants of

113 program participation. Similar results were identified in a related study by Dickinson et al.

114 (2012) which estimated participation of Massachusetts private forest owners across three 
115 hypothetical carbon sequestration programs. The program attributes examined included: contract

116 length $(5,10$ or 15 years $)$, financial incentives ( $\$ 5, \$ 15$ or $\$ 30$ per acre annual revenue), the

117 requirement for a forest management plan to be in place and the stipulation of a penalty for early

118 withdrawal from the program. The results indicated per acre annual revenue was a positive

119 predictor of program enrollment, while contract length, the requirement to have a forest

120 management plan in place and the stipulation of a penalty for early withdrawal were all

121 negatively related to forest owners' intent to enroll. In another study investigating the intentions

122 of Massachusetts forest owners to participate in payments for carbon sequestration programs,

123 Markowski-Lindsay et al. (2011) found shorter contracts (15 years), higher payments (\$1000 per

124 acre per year), the ability to withdraw from the program without penalty and not being required

125 to have a forest management plan in place were positive predictors of program enrollment. The

126 authors note that financial incentives (annual revenue per acre) were very inelastic (i.e., the

127 intent to enroll did not change much as the incentive price increased or decreased, Png 2012).

128 The inelasticity of financial incentives suggests forest owners' participation is likely dependent

129 upon other factors. Markowski-Lindsay et al.'s (2011) study determined the overall probability

130 of enrollment in payments for carbon sequestration programs for Massachusetts forest owners

131 was less than $38 \%$, even when desirable attributes were maximized and undesirable attributes

132 were minimized.

133 Other studies have examined the influence of program attributes associated with

134 payments for other ecosystem services, aside from carbon sequestration (Rabotyagov and Lin

135 2013; Knoot, Rickenbach, and Silbernagel 2015; Kelly, Germain, and Stehman 2015). Knoot et

136 al. (2015) investigated the effect of four cumulative requirement levels (i.e., no requirements,

137 management plan, practices and inspection) and their impact on Wisconsin forest owners' 
138 willingness to participate in programs that offered payments for the provisioning of three 139 ecosystem services: bird habitat, carbon sequestration and water quality. Their results revealed

140 requirements involving more commitment deterred participation; participation rates dropped

141 from $42 \%$ when no requirements were stipulated to $18 \%$ when all of the aforementioned land

142 management practices were required. Knoot et al. (2015) also found that program administration

143 (government or market) held no significant influence on participation across all requirement

144 levels. This is inconsistent with findings from stakeholder focus groups in the Charlotte

145 metropolitan region, which indicated strong anti-government sentiment that could affect forest

146 owners' receptivity to government administered programs in our study area (BenDor et al. 2014).

147 Similarly, Kelly et al. (2015) assessed the likelihood of New York forest owners to enroll in

148 various payments for forest conservation programs. The payments for conservation programs

149 received an average enrollment of $8 \%$ regardless of time commitment. However, financial

150 incentives (annual payment levels) and management plan requirements were significant

151 attributes affecting enrollment. In another similar study, Rabotyagov and Lin (2013) explored the

152 preferences for attributes of working forest conservation contracts among Washington forest

153 owners. Of the three program attributes investigated, contract length significantly influenced the

154 likelihood of program participation. Finally, through focus groups with Forest Guild members,

155 Wade and Moseley (2011) found profitability to be the greatest barrier to private forest owners'

156 enrollment in voluntary payments for carbon sequestration programs. Financial incentives

157 positively affecting enrollment rates is a consistent finding across the literature.

158 Psychological and Sociodemographic Factors Influencing Program Enrollment

159 Aside from the attributes associated with payments for carbon sequestration programs,

160 forest owners' psychological attachments to their property might affect their intent to enroll 
161 (Markowski-Lindsay et al. 2011). However, no previous study has explicitly and empirically

162 examined this relationship. 'Sense of place' is a positive bond between individuals and their

163 environment, based on affect, cognition and symbolic meanings (Stedman 2002). Several studies

164 suggest the sense of place that an individual forest owner has towards their property will affect

165 how they manage that property (Lai and Kreuter 2012; Lokocz, Ryan, and Sadler 2011).

166 Lai and Kreuter (2012) examined how 'place attachment' (a construct very similar to

167 sense of place) influenced Texas landowners' intent to retain their land and engage in

168 conservation behaviors. Much like the forest owners near Charlotte in our study, the landowners

169 examined in Lai and Kreuter's study were facing development pressure from the nearby cities of

170 Austin and San Antonio. Landowners living in the Hill Country region adjacent to the

171 metropolitan areas surrounding both of these cities indicated a strong intent to keep their

172 property in the family. Land owners' attachments to their personal properties, as well as their

173 perceptions of environmental change throughout the region, were significantly and positively

174 related to the intent to retain their properties. In addition, landowners who indicated they were

175 either heavily dependent upon, or attached a lot of social meanings to, their properties were

176 willing to invest more in conservation-oriented land management strategies.

177 Relatedly, Lokocz et al. (2011) utilized photo-elicitation methods to examine how rural

178 Massachusetts residents' psychological attachments to local landscape features influenced their

179 attitudes toward conservation and land use planning. Participants in the study indicated a high

180 level of attachment towards natural areas (consisting of forests, streams, ponds and meadows)

181 and the majority of participants showed strong support for protecting local woodlands and

182 natural resources. The study's qualitative methods illustrate how the strong, personally 
183 meaningful connections an individual has towards local and familiar landscapes can shape 184 support for conservation-oriented land use planning efforts.

In addition to sense of place and place attachment, Thompson and Hansen $(2013 ; 2012)$

186 identified other psychological, cultural and social factors likely to influence individuals'

187 willingness to participate in payments for carbon sequestration programs. These factors included

188 landowners' values, their ecological knowledge, the risk they associate with encroaching 189 development, as well as their willingness to communicate and learn about payments for carbon 190 sequestration programs.

\section{Methods}

\section{Study Region}

This study focused on the area surrounding Charlotte, North Carolina (USA) (Figure 1).

194 Since the 1980s the city and its surrounding metropolitan region have experienced rapid

195 population growth characterized by disjunct, low-density development (Meentemeyer et al.

196 2013). Urban development throughout the region has come at the expense of forest and

197 agricultural lands, and growth projections for the region suggest more than 210,000 ha of

198 forested and agricultural land will be converted to development by the year 2030 if observed

199 trends between 1996 and 2006 continue (Meentemeyer et al. 2013). The majority of forested land

200 throughout the region is owned by non-industrial private forest owners, and these holdings tend

201 to be relatively small ( $<10$ ha), which limits forest owners' ability to financially benefit from

202 either harvesting timber or biomass (Dorning, Smith, et al. 2015). Past research in the region

203 suggests forest owners are concerned with rising property taxes and the lack of tax-relief policies

204 focused on conserving forested lands; this concern is compounded by strong emotional and

205 psychological ties to the region's culturally rich landscapes (BenDor et al. 2014). Currently, 
there are no established policies that provide non-industrial private forest owners with an opportunity to benefit financially from conserving or managing their woodlands (North Carolina Department of Revenue 2015). The region does have a present-use value program that allows

209 land to be valued based upon its use for forestry or agriculture, which is substantially less than its

210 development value. However, not all forested land throughout the region qualifies for the

211 present-use value program. The program requires forest owners to own at least 20 acres (8.09

212 hectares) and have a forest management plan in place that allows timber harvesting. These

213 requirements limit the ability of the present-use value program to be an indirect tool capable of

214 slowing urban growth. Given this, other more direct land use policies need to be explored. It is

215 possible a regional carbon sequestration market could allow forest owners the ability to benefit

216 financially from conserving or managing their woodlands while maintaining their strong

217 emotional and psychological connections to their properties.

218 Discrete Choice Experimental Design

219 We developed a discrete choice experiment to explore contingent forest owner behaviors

220 in response to hypothetical payments for carbon sequestration programs. Stated choice methods

221 are commonly used to understand individuals' behavioral responses to hypothetical choices

222 (Louviere, Hensher, and Swait 2000). Our goal was to understand which factors exhibit the most

223 influence on forest owners' behavioral intentions, including the attributes of the payment

224 program as well as individual psychological and sociodemographic factors. Our analysis was

225 guided by a desire to better understand if, and how, the attributes of the payment program alterd

226 forest owners' preferences for those programs. Our intent was not to estimate a willingness to

227 accept value for all of the non-financial attributes of payments programs, rather we were

228 primarily interested in taking advantage of the methodological benefits of discrete choice 
experiments (i.e., requiring respondents to cognitively evaluates specific trade-offs among program attributes (Hanley, Mourato, and Wright 2001)) to develop a better understanding of the

231 program attributes forest owners considered important when contemplating enrolling in a 232 payments for carbon sequestration program.

234 private forest owners would enroll in payments for carbon sequestration programs, we were specifically interested in whether or not financial incentives, contract lengths and program

236 administration influences individuals' contingent behaviors. These three factors were combined

237 and varied across meaningful ranges to create a suite of hypothetical, yet realistic, payments for

238 carbon sequestration programs. For each program, forest owners were asked to carefully consider

239 the combination of attributes being presented and make a "yes/no" choice as to whether or not

240 they would participate in the program. A "yes" response indicates forest owners derive more

241 utility from participating in the program than they would otherwise. Utility formulation for each

242 binary discrete choice made in response to a hypothetical program follows the random utility

243 framework (McFadden 1973). Across an entire set of choices, $j$, and a sample of individuals, $i$,

244 the linear equation used to estimate random and explainable (systematic) utility is expressed as

248 The explainable (systematic) utilities $V_{i j}$ are a function of the design matrix $X$, which represents

249 attributes presented in various combinations across the choice set. The $\beta^{\prime}$ coefficients are 250 estimated for each attribute. 
Scenario Development, Attributes and Levels. To elicit the most valid responses, the survey instrument included a narrative frame describing the general characteristics of payments

253 for carbon sequestration programs and how they could be implemented in the study region.

254 Following the narrative framing statement, forest owners were asked to evaluate a set of nine

255 possible payments for carbon sequestration programs and, for each program, to carefully

256 consider its attributes and indicate whether or not they would participate in the program.

257 Respondents were also given an opt out response option to avoid the likelihood of a forest owner

258 providing a response if they felt uninformed or unqualified to make a decision (Banzhaf,

259 Johnson, and Mathews 2001; Kontoleon and Yabe 2003). The choice set was comprised of

260 various combinations of the three key attributes: financial incentives, contract lengths and

261 program administration. Each of these three attributes were varied across three levels; the levels

262 were set to encompass realistic ranges based upon previous research and consultation with

263 experts in the region's potential for a carbon sequestration market. The full narrative frame and

264 choice set are shown in Figure 2; individual attributes and their specified levels are noted in

265 Table 1. The narrative was developed such that it clearly described the essential components of a

266 payments for ecosystem services program, as outlined by Engel et al. (2008). These essential

267 components are: 1) an explicit description of the type of land being conserved and the ecosystem

268 service it provides; 2 ) the ability of enrollees in the program to terminate the contractual

269 relationship; and 3) the establishment of a monitoring system (in our case a written forest

270 management plan that required conservation) in order to ensure payments are the result of

271 additional land management activities. Given payments for ecosystem services programs often

272 fail to demonstrate additionality, producing more of a given ecosystem service than would have

273 been produced without the program, we attempted to make it as clear and as explicit as possible 
274 that the payments would not be "money for nothing" (Engel, Pagiola, and Wunder 2008; Ferraro 275 and Pattanayak 2006).

276 With three attributes, each presented at one of three levels in any given program, there

277 were a total of 27 possible combinations to represent different carbon sequestration programs.

278 Given it was deemed too burdensome to have each forest owner consider and respond to all 27

279 combinations, we opted for a fractional factorial design comprised of nine combinations (i.e.,

280 hypothetical payments for carbon sequestration programs). All sampled forest owners received

281 the same choice set of nine possible carbon sequestration programs.

\section{Variables Used in Econometric Model}

A summary of all variables used in the econometric modeling is provided in Table 2.

284 Respondents' sociodemographic characteristics were captured through the first mail-back survey.

285 Specifically, we collected data on forest owners' age, gender, education and income. We also

286 collected data on the amount of time the forest owner has spent on the property (presence); this

287 was calculated as the total years of ownership multiplied by the number of days they spend on

288 the property per year. The first mail-back survey also ascertained whether or not respondents had

289 a forest management plan in place (management plan present) and whether they currently

290 harvested timber for income on their property (harvest for income).

291 The first mail-back survey was also used to measure forest owners' psychological

292 connections to forested areas on their properties. We used Jorgensen and Stedman's (2006)

293 psychometric scale, modifying each statement so that it referred explicitly to respondents'

294 forested property. Data obtained via the 5-point Likert scale were analyzed for reliability

295 (Cronbach's $\alpha$ greater than 0.70 were deemed acceptable following Nunnally and Bernstein

296 1994), adequate factor loadings (loadings greater than 0.60 were deemed acceptable following 
297 Hair et al. 2009) and their fit to a hypothesized single-factor measurement model (relative $\chi^{2}$

298 values less than 3.0 were deemed acceptable following Carmines and McIver 1981). With these

299 criteria satisfied, a single sense of place factor score was calculated for inclusion in the mixed

300 effects logistic regression model described below. This method is identical to that used in

301 previous analyses of these data (Dorning, Smith, et al., 2015).

302 Other variables included in the model were derived from either the analysis of satellite

303 imagery/LiDAR data or publically available property tax records. Specific measures included the

304 size of the forest stand on the respondent's property estimated via satellite imagery (forest size)

305 and the appraised value of the parcel extracted from 2011 tax records (economic value). Very

306 few stated choice experiments have used biophysical variables derived via remote sensing as

307 factors influencing forest owners' decisions; exceptions include the work of Naidoo and

308 Adamowicz (2005) and Dorning and her colleagues (2015).

309 Econometric Model Specification

310 We used a mixed effects logistic regression specification to estimate the probability that

311 forest owners would participate in payments for carbon sequestration programs depending upon

312 the level of attributes presented. The mixed effects logistic regression is a flexible specification

313 that can approximate any random utility model (McFadden and Train 2000). The mixed effects

314 logistic regression specification decomposes random error into two components; the first

315 component is correlated over alternatives and heteroskedastic while the second part is assumed

316 to be independently and identically distributed over alternatives and individuals (McFadden

317 1984). This is noteworthy because individuals' responses within the choice set are likely to be

318 highly correlated. Preferences and subsequently utility functions will vary between individuals;

319 the mixed effects specification accommodates this and is commonly used to overcome the 
320 limitations of standard logit and conditional logit specifications (McFadden and Train 2000). Our

321 model is specified as:

322

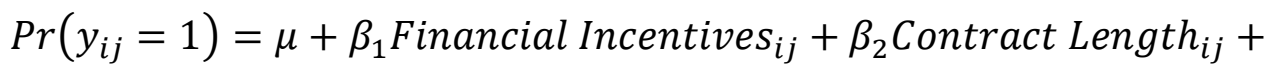

$\beta_{3}$ Program Administration $_{i j}+\beta_{4}$ Age $_{i}+\beta_{5}$ Education $_{i}+\beta_{6}$ Gender $_{i}+\beta_{7}$ Income $_{i}+$

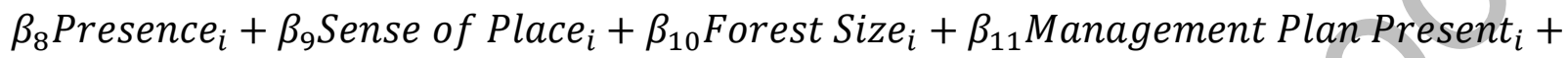

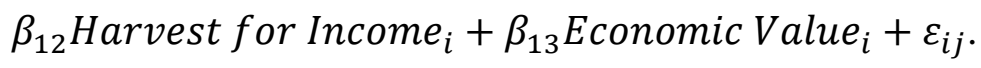

The model posits the probability of enrolling in payments for carbon sequestration programs is a

329 function of the program's attributes, an individual's sociodemographic characteristics and the

330 characteristics of their property. Estimation was completed using dummy variable coding for

331 attribute levels and the meqrlogit command in Stata 14.0 (StataCorp 2015).

\section{Data Collection}

Data on forest owners and their contingent enrollment in hypothetical payments for

334 carbon sequestration programs were collected via two self-administered mail-back surveys. We sent surveys to a sample of forest owners in a five-county region on the eastern side of Charlotte,

336 an extent characterizing the region's full development gradient. We drew a sample of 2,500

337 landowners from a sampling frame comprised of private forest owners within the five-county

338 study area; forest owner names and addresses were obtained from publically available tax

339 records. The sample consisted of forest owners who owned more than 2 ha of contiguous forest

340 (determined via analysis of both 2011 Landsat and LiDAR data (Singh et al. 2012)). The initial

341 sample of forest owners were asked to agree to an on-site ecological assessment and timber

342 cruise of their property and, subsequently, to complete two mail-back surveys; a total of 143 
343 (5.7\%) forest owners agreed. The first mail-back survey was administered from November 2011

344 to April 2012; it asked about forest owners' sociodemographic characteristics, how they

345 managed woodlands on their property as well as their psychological attachment to their property.

346 A total of 126 out of the 143 woodland owners (88\%) completed this first mail-back survey. The

347 second mail-back survey was administered in November 2013 to the 126 forest owners who

348 responded to the first survey. The second mail-back survey was substantially shorter than the

349 first, containing only a series of stated preference questions related to the forest owners'

350 willingness to participate in payments for carbon sequestration programs. A total of 65 forest

351 owners, out of the 126 who received the second mail-back survey, completed and returned the

352 instrument. This tabulates out to a $49.6 \%$ response rate, which is high relative to most mail

353 surveys administered to either the general public or forest owners (Dillman, Smyth, and

354 Christian 2008). Five respondents indicated their property had been sold since they responded to

355 the first mail-back survey two years earlier. All results presented in this study are for the 356 remaining 60 forest owners and their properties.

357 Both survey packets mailed to respondents included a personalized map with an aerial 358 photo of forested land on the respondents' property. In a cover letter, we asked forest owners to

359 respond to the questions in reference to the forested land shown on the map, excluding from

360 consideration other forested areas they might have owned. These explicit instructions were

361 included to make responses and contingent decisions personally meaningful.

\section{Results}

The characteristics of our sample of forest owners and their properties are reported in

364 Table 2. The majority of respondents $(71.7 \%)$ were men and the mean age was $64.2(S D=11.2)$.

365 All respondents had graduated from high school, with the majority (68.3\%) also having a 
bachelor's degree. Respondents' properties ranged in size from one to fifty-one hectares, with an average size of 6.9 hectares $(S D=8.4)$. On average, respondents indicated owning their forestland for at least twenty years $(M=20.4, S D=12.8)$; this varied widely however, with

369 length of ownership ranging from two to fifty-eight years. The majority of respondents $(68.3 \%)$

370 lived on or within a half-mile of the forested property.

371 The average size of respondents' forests was 6.9 hectares $(S D=8.4)$ and the assessed tax

372 value of their entire property was just under \$400 thousand USD. However, both the size of

373 respondents' forest stands and the value of their properties varied widely (Table 2), mitigating

374 some of the concern over coverage error given the relatively small sample. Only a relatively

375 small proportion (18.3\%) of our sample reported harvesting timber to generate income and just

376 under one-third (31.7\%) reported having a management plan in place.

When queried about the sense of place respondents had towards their forested property,

378 respondents on average reported strong personal meanings (Table 3). For example, 77.2\% of

379 sampled forest owners indicated moderate or complete agreement with the statement "I feel

380 relaxed when I'm on my wooded land." Similarly, $62.5 \%$ of the sample indicated moderate or

381 complete agreement with the statement "I feel happiest when I'm on my wooded land."

The results from the hierarchical mixed effects logistic regression model, which predicted

383 forest owners' intent to enroll in payments for carbon sequestration programs, are shown in

384 Table 4. The model's estimates can be interpreted as the welfare of each attribute's level. For the 385 non-price attributes (contract length and program administration) and the price attribute (per acre annual payment), increases (decreases) in welfare are indicated by positive (negative) values. The results revealed annual payment levels do significantly influence individuals'

388 likelihood of enrolling. The odds of a forest owner enrolling in a payments for carbon 
sequestration program were 18.5 times higher if that program yielded $\$ 25$ per acre annual

payments as opposed to $\$ 5$ per acre annual payments $($ Coef. $=2.917, p<0.001)$. More notably,

391 the odds of a forest owner enrolling in a payments for carbon sequestration program were nearly

392110 times greater if the program resulted in $\$ 50$ per acre annual payments instead of $\$ 5$ per acre

393 annual payments (Coef. $=4.702, p<0.001)$. These results supported our proposed hypothesis

$394\left(\mathrm{H}_{1}\right)$ that financial incentives would positively influence individuals' intent to enroll in payments

395 for carbon sequestration programs.

396 The results also revealed contract length significantly influences individuals' likelihood

397 of enrolling, with respondents preferring shorter contracts (15-year contract, Coef. $=-2.266, p<$

398 0.001; 30-year contract, Coef. $=-4.855, p<0.001)$. While contract length was significant, its

399 influence was marginal relative to the effect of annual payment levels, which exhibited a very

400 strong signal. This result supported our proposed hypothesis $\left(\mathrm{H}_{2}\right)$ that contract length would

401 negatively influence individuals' intent to enroll in payments for carbon sequestration programs.

402 The final attribute of the hypothetical programs, the type of agency administering the

403 program, was not significantly related to individuals' intent to enroll (Administered by a state

404 agency: Coef. $=0.451, p=0.266$; Administered by a federal agency: Coef. $=0.613, p=0.291$ ).

405 This result followed our proposed hypothesis $\left(\mathrm{H}_{3}\right)$ that the type of organization administering a

406 payments for carbon sequestration program would not influence individuals' intent to enroll.

407 The results also suggested forest owners' education level and income influenced their

408 intent to enroll in payments for carbon sequestration programs. Forest owners who had obtained

409 a higher level of formal education were significantly more likely to enroll in a program,

410 regardless of program characteristics $($ Coef. $=0.597, p<0.045)$. Additionally, wealthier

411 individuals were significantly less likely to enroll in a program, regardless of program 
412 characteristics (Coef. $=-0.286, p<0.082)$. None of the other characteristics describing forest

413 owners (age, gender, presence on the property or sense of place) were significantly related to

414 their intent to enroll in a program. The finding of no significant relationship between forest

415 owners' sense of place towards their forested property and their willingness to enroll that

416 property in a payments for carbon sequestration program was dissimilar to our proposed

417 hypothesis of a positive relationship $\left(\mathrm{H}_{4}\right)$.

418 None of the characteristics of forest owners' property (size of forest stand, the presence

419 of a management plan, whether or not timber was harvested for income generation or economic

420 (property) value) were significant predictors of the forest owners' intent to enroll in payments for

421 carbon sequestration programs.

422 We began this investigation by posing the question "Can a payments for carbon

423 sequestration program alleviate development pressure in a rapidly urbanizing region?” We

424 formally addressed this question by calculating the annual revenue generated by each of the

425 hypothetical payments for carbon sequestration programs for each forest owner. For each forest

426 owner $i$ and each discrete choice opportunity $c$, this is

427

428 Annual revenue $_{i c}=$ annual payment per acre a $_{c} \times$ forested acres $_{c}$.

430 The average initial annual revenue required to elicit an intent to enroll response varied widely, 431 from $\$ 51$ per acre for policies guaranteeing a $\$ 5$ per acre annual payment, to $\$ 753$ per acre for 432 policies guaranteeing a $\$ 50$ annual payment. After calculating all of the initial annual revenues 433 for the choice opportunities in which a forest owner indicated an intent to enroll, we applied an 434 annual discount rate of $4 \%$ across the hypothetical contracts' lengths to account for the time 
435 value of cash according to Folmer et al. (1995). This allowed us to arrive at a total discounted

436 contract length revenue value. Our calculation was based on the assumption annual revenue

437 would be received beginning in the second year of enrollment. The variation in intent to enroll

438 prices was even more evident when viewed over the life of the contract; average discounted

439 contract length revenue ranged from $\$ 190$ per acre for the $\$ 5$ per acre policies to $\$ 8,540$ for the

$440 \$ 50$ per acre policies.

441 We estimated the years of enrollment that would be required for respondents to receive

442 equal returns from a payments for carbon sequestration program relative to returns they would

443 receive from either cutting all of their forest for timber or selling it at its current (2014) market

444 value; the results are shown in Table 5. If a payments for carbon sequestration program were

445 available that yielded the maximum $\$ 50$ per acre annual return over a 15 -year contract length,

446 forest owners would not be able to generate an equivalent amount of revenue from the program,

447 even if they enrolled for two consecutive contracts (years of enrollment to match timber value $=$

448 38.4). This result suggests that even under the highest-return option and a relatively long

449 contract-length program, a payments for carbon sequestration program would not be an attractive

450 alternative to either selling property for development or harvesting for timber. As can be seen in

451 column 6 of Table 5 the years of enrollment required to equal their properties' current market

452 value is well beyond any planning time frame (i.e., 600 to $>13,000$ years). Obviously there are a

453 variety of factors that affect forest owners' decisions to sell their property for development or

454 harvest it for timber production; the purpose here is to compare the options purely on their

455 financial returns.

\section{Discussion}

\section{Policy Implications}


As exurban development spreads across landscapes, large contiguous tracts of forest have become increasingly fragmented, threatening the ecosystem services they provide (Theobald 2005; Theobald 2001; Theobald and Romme 2007). Payments for ecosystem service programs,

461 and payments for carbon sequestration in particular, provide a mechanism through which

462 regional planners and policy makers can conserve urban-proximate forestlands and the

463 ecosystem services they provide by allowing private forest owners to benefit financially from not

464 selling their land for development or harvesting for timber production (Bigsby 2009). Alternative

465 policy mechanisms, such as the procurement and conservation of private forestland by a public

466 or not-for-profit organization, can also alleviate development pressure (Newburn et al. 2005).

467 However, transferring land from the private to public domain is only likely to occur near highly

468 valued resources such as riparian areas, simply pushing development pressures to other areas

469 around a metropolitan region (Dorning, Koch, et al. 2015). Additionally, the efficient transfer of

470 private land to the public-domain requires complex payment and/or transfer options capable of

471 meeting the needs of different types of private landowners (e.g., rural residents, farmers, forest

472 owners) (Nielsen-Pincus, Ribe, and Johnson 2015). Payments for carbon sequestration programs

473 offer a flexible policy alternative, allowing forest owners the ability to continue living on their

474 properties while simultaneously receiving an annual payment for the carbon being sequestered

475 and stored in their forest stands.

While payments for carbon sequestration programs are attractive policy mechanisms at a

477 conceptual level, their implementation has been severely limited by the lack of regional carbon

478 markets (Newell, Pizer, and Raimi 2013). In the United States, the voluntary Chicago Climate

479 Exchange (CCX) served as the primary outlet for such programs while in operation from 2003 to

480 2011. Currently, there are only two active regional markets, California and the Regional 
481 Greenhouse Gas Initiative (RGGI) in the northeastern portion of the country (Center for Climate

482 and Energy Solutions 2016). These markets establish the price per ton of carbon sequestered

483 based upon industries' need to offset emissions and private forest owners' willingness to manage

484 their forests for carbon sequestration. In this research, we leveraged the ability of discrete choice

485 experiments to determine if a payments for carbon sequestration program could succeed in the

486 southeastern United States, where exurban forest owners are highly attached to their private

487 lands and consequently may be more willing to opt into payments for carbon sequestration

488 programs at a discounted rate, if it means their forest will remain intact.

On many points, our results echoed the findings of previous research. Our sample of

490 forest owners expressed a relatively limited interest in enrolling in payments for carbon

491 sequestration programs. Even when presented with a very large annual payment of $\$ 50$ per acre,

492 only $45.8 \%$ of respondents indicated an intent to enroll; this proportion declined as annual

493 payments were reduced and contract lengths were extended. This result is consistent with

494 previous research (Fletcher, Kittredge, and Stevens 2009; Markowski-Lindsay et al. 2011;

495 Miller, Snyder, and Kilgore 2012; Miller et al. 2014) and perhaps expected given most private

496 forest owners in the United States are passive managers. We had expected a higher level of

497 interest in payments for carbon sequestration programs given a recent region-wide study found

498 non-industrial private forest owners to be generally receptive to payments for carbon

499 sequestration programs (Khanal et al. 2016). Khanal and his colleagues found $30 \%$ of a sample

500 of non-industrial forest owners from across the Southeastern US agreed with the statement

501 "carbon sequestration could generate additional revenue for me"; only 11\% of the sample

502 disagreed with the statement. Similarly, $45 \%$ of the sample indicated they were "interested in 
503 exploring carbon sequestration opportunities on [their] forestland"; only $12 \%$ were not

504 interested.

505 Our sample's low level of interest in enrolling in payments for carbon sequestration

506 programs is likely attributable to a variety of factors. First, they are likely to have a limited

507 knowledge of the 'ecosystem services' concept and, relatedly, are likely to know very little about

508 how carbon markets would actually work in practice (Metz and Weigel 2010). Given this, it is

509 logical for forest owners to be hesitant about making, or even indicating their preferences for,

510 decisions related to the long-term use of their property. More focused research, particularly

511 research using multiple types of data (i.e., quantitative and qualitative), needs to be conducted to

512 determine if a lack of knowledge and familiarity are in fact major barriers to forest owners'

513 intent to enroll in emerging carbon markets. Second, through the use of a stated choice

514 experiment, our study required forest owners to carefully consider their forested property and

515 what the consequences of each hypothetical policy scenario would be for themselves and their

516 property. Previous research may have over-estimated forest owners' interest in carbon

517 sequestrations programs due to the fact simple statement items presented in mail-back

518 questionnaires are context-deficient and do not require forest owners to carefully consider the

519 details and consequences of their land-use decisions (Khanal et al. 2016).

520 When our sample of forest owners did indicate an intent to enroll, their preferences were

521 influenced by the financial returns yielded by the program as well as its length. Respondents had

522 strong preferences for programs yielding higher returns, which is logical and consistent with all

523 previous empirical research (Fletcher, Kittredge, and Stevens 2009; Dickinson et al. 2012;

524 Markowski-Lindsay et al. 2011; Rabotyagov and Lin 2013; Knoot, Rickenbach, and Silbernagel

525 2015; Kelly, Germain, and Stehman 2015; Miller, Snyder, and Kilgore 2012; Miller et al. 2014). 
526 The majority of previous research has also found non-industrial private forest owners tend to be

527 hesitant to make long-term decisions committing them to managing their forestlands in any one

528 particular way (Dickinson et al. 2012; Markowski-Lindsay et al. 2011; Newell, Pizer, and Raimi

529 2013; Miller, Snyder, and Kilgore 2012; Miller et al. 2014). This unfortunately does not bode

530 well for the prospect of establishing a regional payments for carbon sequestration market within

531 the study area. At the high point of the CCX (trading price of \$7.50 per metric ton in 2008;

532 Climate Policy Initiative 2016)), the maximum potential payments in the Southeast would have

533 been around $\$ 15$ per acre per year based on CCX's estimated carbon sequestration rates across

534 all Southeastern forest types. Current rates for the RGGI are even lower though their reports

535 suggest prices are generally increasing over time, while trading prices in California are generally

536 a bit higher (Climate Policy Initiative 2016). These markets have required contracts of a

537 minimum of 15 years (CCX), with longer contracts (RGGI) sometimes required. Creation of a

538 market in the Southeast would require a critical mass of tradable carbon, in this case, a large pool

539 stored in private forests under long-term management contracts. For regional markets to be

540 successful, industries that might see them as viable mechanisms to offset emissions would need

541 some long-term assurances in the market's stability. Absent that stability, alternative

542 mechanisms or alternative carbon markets (e.g. REDD+) are likely to be preferred.

543 We focused our survey on payments for carbon sequestration based on market prices for

544 similar markets in the U.S., though other carbon payment mechanisms do exist. Payments for

545 carbon storage, or avoided carbon release from deforestation, would likely provide much higher

546 payment rates than those for sequestration as forest owners would be compensated for the total

547 amount of carbon stored rather than incremental carbon sequestered. Additionally, estimates of

548 the social cost of carbon at \$36 per metric ton (Interagency Working Group on the Social Cost of 
549 Carbon 2013) far exceed the current value in most markets, bringing the potential payment level

550 up to $\$ 72$ per acre per year for carbon sequestered in Southeastern forests if the true cost of

551 carbon were to be reflected in market prices (though Moore and Diaz (2015) argue the figure

552 should be much higher). Given the preference of forest owners for greater financial returns,

553 higher payment rates could increase the feasibility of carbon programs for alleviating

554 development pressure in urbanizing areas.

555 Despite the relative ambivalence of forest owners towards participating in payments for

556 carbon sequestration programs at current rates and their aversion to programs with longer

557 contract lengths, our results did identify some demographic groups that can be targeted as 'early

558 adopters' to pilot payments for carbon sequestration programs. Specifically, our results

559 suggested more educated individuals as well as individuals with smaller incomes were

560 significantly more likely to indicate intent to enroll relative to forest owners with fewer years of

561 formal education and wealthier individuals. These findings could be insightful for efficiently

562 targeting specific types of forest owners most likely to participate in a pilot payments for carbon

563 sequestration program, if one were initiated throughout the region. These findings can be used to

564 develop communication strategies targeted at specific forest owners that are most likely to enroll.

565 Given our findings suggest the populations most likely to enroll are those forest owners who are

566 more educated and who also have smaller annual incomes, the logical 'target population' would

567 be retirees looking to maintain the aesthetic appeal of their forested land while also having some

568 formal policy mechanism that would allow them to generate a cash-flow from their passive

569 ownership.

$570 \quad$ It is interesting to note forest owners' sense of place was not significantly related to their

571 intent to enroll in payments for carbon sequestration programs. This is especially noteworthy 
572 given forest owners, on average, indicated strong personal meanings attached to their forested

573 property. Previous research into payments for ecosystem services programs suggests that when

574 the amount of the payment itself is marginal relative to landowners' other sources of income (as

575 is the case in our study area), the larger the influence of other benefits such as maintaining a

576 desired aesthetic or family/cultural values tied to the land (Muradian et al. 2010). We can only

577 speculate as to why sense of place was not significantly related to forest owners' willingness to

578 enroll, as anticipated. One possible explanation is that simply having the word 'program'

579 attached may cause forest owners to wrongfully identify payments for carbon sequestration

580 programs with other more intensive programs, such as present use valuation programs. Simply

581 put, some forest owners may not associate payments for carbon sequestration programs with an

582 increased ability to maintain the non-market values they ascribe to their forested property,

583 marginalizing the true and expected relationship between the sense of place construct and

584 willingness to enroll. Payment may actually be viewed as undermining the intrinsic values the

585 forest owner wishes to protect (Muradian et al. 2013).

586 Limitations

587 Estimating the utilities associated with the attributes of hypothetical policies and

588 programs via stated choice methods is a difficult task for economists and other social scientists

589 who focus on human decision making. This difficulty comes from a variety of different sources

590 ranging from deciding which attributes define the hypothetical policy or program to establishing

591 a realistic range of values across which those attributes will vary in the choice set. Attributes and

592 levels selected should be both understandable (DeShazo and Fermo 2002) and relevant (Hensher

593 2006) to respondents. In this study, we attempted to meet both of these criteria through a detailed

594 review of previous research on the feasibility and costs associated with payments for carbon 
sequestration programs and consultation with several bioeconomists who were able to inform the

596 levels we chose to use for our annual payments per acre attribute. While we hope this

597 precautionary step increases the validity of our findings, there are undoubtedly a wide variety of

598 program characteristics (e.g., method of payment, compliance requirements, etc.) that also likely

599 to influence forest owners' willingness to enroll in payments for carbon sequestration programs.

600 We were only able to focus on a small set of attributes within this study, but hope future research 601 will build upon our findings and the findings of similar work (Table 1).

Another difficulty in estimating the utilities associated with the attributes of hypothetical

603 policies and programs via stated choice programs is the proper analytical treatment of collected

604 data. Resource economists have gradually adapted more complex and sophisticated statistical

605 specifications, moving from the simple binary logit model to the multinomial logit model to the conditional logit model and now the mixed effects logit model (Hensher and Greene 2002). With

607 the addition of each additional specification comes a new set of assumptions that analysts must

608 be wary of. Here, we used a mixed logit model with one random parameter, the individual, that

609 we specified as being normally distributed. Our specification is not analytically novel, but it does

610 mitigate all of the concerns raised by Hensher and Greene (2002). These concerns include:

611 appropriate selection of parameters to be included as random parameters, appropriate selection of

612 the distribution of the random parameters and appropriate specification of the way random

613 parameters enter the model. We felt the mixed logit specification was appropriate given it relaxes

614 independence of irrelevant alternatives property inherent in standard logit and conditional logit

615 models and subsequently allows response variable to be correlated across the choice situations

616 presented to each individual (Train 2009). Future work that chooses to used stated preference

617 data to estimate forest owners' intent to enroll in payments for carbon sequestration programs, 
618 and chooses to fit those data with mixed effects logit specifications should be mindful of the

619 concerns detailed by Hensher and Greene (2002)

\section{Conclusion}

We began this investigation to determine forest owners' willingness to enroll in a

622 payments for carbon sequestration market in an urbanizing region. In our study area surrounding

623 metropolitan Charlotte, the potential for market failure is high as urbanization is rapidly

624 consuming the landscape (Meentemeyer et al. 2013; Terando et al. 2014). Even if private forest

625 owners are committed to not developing their properties, they can benefit financially from stands

626 on their property by harvesting them for timber production. Both development and harvesting for

627 timber production are financially enticing, but dramatically alter the ecological function of the

628 landscape. While the majority of forest owners in our study were reluctant to indicate an intent to

629 enroll in payments for carbon sequestration programs, we did identify several groups of forest

630 owners likely to capitalize on the benefits provided by payments for ecosystem services

631 programs, namely the ability to receive annual revenue capable of offsetting rising property taxes

632 and the ability to maintain non-market values such as local aesthetics and recreation use values.

633 If a payments for carbon sequestration program could be combined with payments for other

634 ecosystem services such as water quality and wildlife habitat, it is possible these individuals

635 would be even more likely to see these 'alternative' forest management programs as viable

636 mechanisms from which they could benefit financially and maintain the strong personal

637 meanings they hold towards their forestlands. Programs could become even more attractive if

638 payments accounted for carbon already stored or the social cost of carbon. On a strategic level,

639 payments for carbon sequestration programs offer the promise of preserving local ecological 
640 structure and function while simultaneously enabling forest owners to benefit financially from

641 the public goods they provide to society. 
This research was funded by the NSF ULTRA-EX Program (Award Number: 0949170).

3 Any use of trade, product or firm names is for descriptive purposes only and does not imply

4 endorsement by the U.S. Government. 
Table 1

Carbon sequestration program attributes and levels examined using stated choice methods in this, and previous, research

\begin{tabular}{|c|c|c|c|c|c|c|c|c|c|c|c|c|}
\hline \multirow[b]{3}{*}{ Previous research } & \multicolumn{12}{|c|}{ Attribute and Levels } \\
\hline & \multicolumn{3}{|c|}{$\begin{array}{c}\text { Financial } \\
\text { incentives (annual } \\
\text { payment per acre } \\
\text { (USD)) }\end{array}$} & \multicolumn{3}{|c|}{$\begin{array}{c}\text { Contract } \\
\text { length (yrs.) }\end{array}$} & \multicolumn{3}{|c|}{ Program administration } & \multicolumn{3}{|c|}{$\begin{array}{l}\text { Geographic region of the United States } \\
\text { North }\end{array}$} \\
\hline & $\begin{array}{c}>5 \\
\text { to }< \\
25\end{array}$ & $\begin{array}{l}\geq 25 \\
\text { to }< \\
50\end{array}$ & $\geq$ & 5 & 15 & 30 & $\begin{array}{c}\text { State } \\
\text { agency }\end{array}$ & $\begin{array}{l}\text { Federal } \\
\text { agency }\end{array}$ & $\begin{array}{l}\text { Private } \\
\text { company }\end{array}$ & $\begin{array}{l}\text { Atlantic } \\
\text { and New } \\
\text { England }\end{array}$ & $\begin{array}{l}\text { Northern } \\
\text { Midwest }\end{array}$ & $\begin{array}{c}\text { Pacific } \\
\text { Northwest }\end{array}$ \\
\hline $\begin{array}{l}\text { Fletcher, } \\
\text { Kittredge, and } \\
\text { Stevens } 2009\end{array}$ & $\checkmark$ & $\checkmark$ & & $\checkmark$ & & & & & & & $\checkmark$ & \\
\hline $\begin{array}{l}\text { Dickinson et al. } \\
2012\end{array}$ & $\checkmark$ & $\checkmark$ & & $\checkmark$ & $\checkmark$ & & & & & & $\checkmark$ & \\
\hline $\begin{array}{l}\text { Markowski- } \\
\text { Lindsay et al. } \\
2011\end{array}$ & $\checkmark$ & & $\checkmark$ & & $\checkmark$ & $\checkmark$ & $\checkmark$ & $\checkmark$ & $\checkmark$ & & & \\
\hline $\begin{array}{l}\text { Knoot, } \\
\text { Rickenbach, } \\
\text { and Silbernagel } \\
2015\end{array}$ & $\checkmark$ & $\checkmark$ & $\checkmark$ & & & & & $\checkmark$ & $\checkmark$ & & 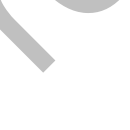 & $\checkmark$ \\
\hline Miller et al. 2014 & $\checkmark$ & $\checkmark$ & $\checkmark$ & & $\checkmark$ & $\checkmark$ & & & & & & $\checkmark$ \\
\hline $\begin{array}{l}\text { Rabotyagov and } \\
\text { Lin } 2013\end{array}$ & & & & $\checkmark$ & & $\checkmark$ & & & & & & $\checkmark$ \\
\hline $\begin{array}{l}\text { Miller, Snyder, } \\
\text { and Kilgore } \\
2012\end{array}$ & $\checkmark$ & $\checkmark$ & $\checkmark$ & $\checkmark$ & $\checkmark$ & $\checkmark$ & & & & & & $\checkmark$ \\
\hline $\begin{array}{l}\text { Kelly, Germain, } \\
\text { and Stehman } \\
2015\end{array}$ & & & $\checkmark$ & & & $\checkmark$ & & & & $\checkmark$ & & \\
\hline $\begin{array}{l}\text { Finley and } \\
\text { Kittredge } 2006\end{array}$ & & & & $\checkmark$ & & & & & $\checkmark$ & & & \\
\hline $\begin{array}{l}\text { Wade and } \\
\text { Moseley } 2011\end{array}$ & & & & & & & & & & $\checkmark$ & $\checkmark$ & \\
\hline $\begin{array}{l}\text { Note. Other progra } \\
\text { Dickinson et al. } 20 \\
\text { and Stehman } 2015 \text {; } \\
\text { and Stevens } 2009 \text {; } \\
\text { and/or timber right } \\
\text { (Markowski-Lindsa }\end{array}$ & $\begin{array}{l}\text { attribut } \\
\text {; Mark } \\
\text { Jade an } \\
\text { ckinsor } \\
\text { onveye } \\
\text { et al. 2 }\end{array}$ & $\begin{array}{l}\text { es inves } \\
\text { wski-L } \\
\text { d Mose } \\
\text { et al. } 2 \\
\text { d (Kelly } \\
\text { )11: Ra }\end{array}$ & $\begin{array}{l}\text { igate } \\
\text { ndsay } \\
\text { ey } 20 \\
12 ; 1 \\
\text { Ger }\end{array}$ & $\mathrm{n}$ th & litar & $\begin{array}{l}\text { ure: T } \\
\text { Rabot } \\
1.201 \\
\text { ndsay } \\
\text { aman }\end{array}$ & $\begin{array}{l}\text { require } \\
\text { gov and I } \\
\text { Finley a } \\
\text { al. } 2011 \\
15 \text { ); insp }\end{array}$ & $\begin{array}{l}\text { nt of a ma } \\
2013 ; \mathrm{Kn} \\
\text { Kittredge } \\
\text { payment } \mathrm{n} \\
\text { tions (Kno }\end{array}$ & $\begin{array}{l}\text { gement pla } \\
\text { t, Rickenb } \\
\text { D06); an ea } \\
\text { de (Kelly, } \\
\text { Rickenba }\end{array}$ & $\begin{array}{l}\text { Fletcher, K } \\
\text {, and Silbe } \\
\text { withdrawal } \\
\text { main, and } \\
\text { and Silber }\end{array}$ & $\begin{array}{l}\text { dge, and St } \\
\text { el 2015; Ke } \\
\text { alty (Fletch } \\
\text { man 2015); } \\
1 \text { 2015); en }\end{array}$ & $\begin{array}{l}\text { ns 2009; } \\
\text { Kittredge, } \\
\text { lelopment } \\
\text { led acreage }\end{array}$ \\
\hline
\end{tabular}


Table 2

Characteristics of sampled forest owners and their properties

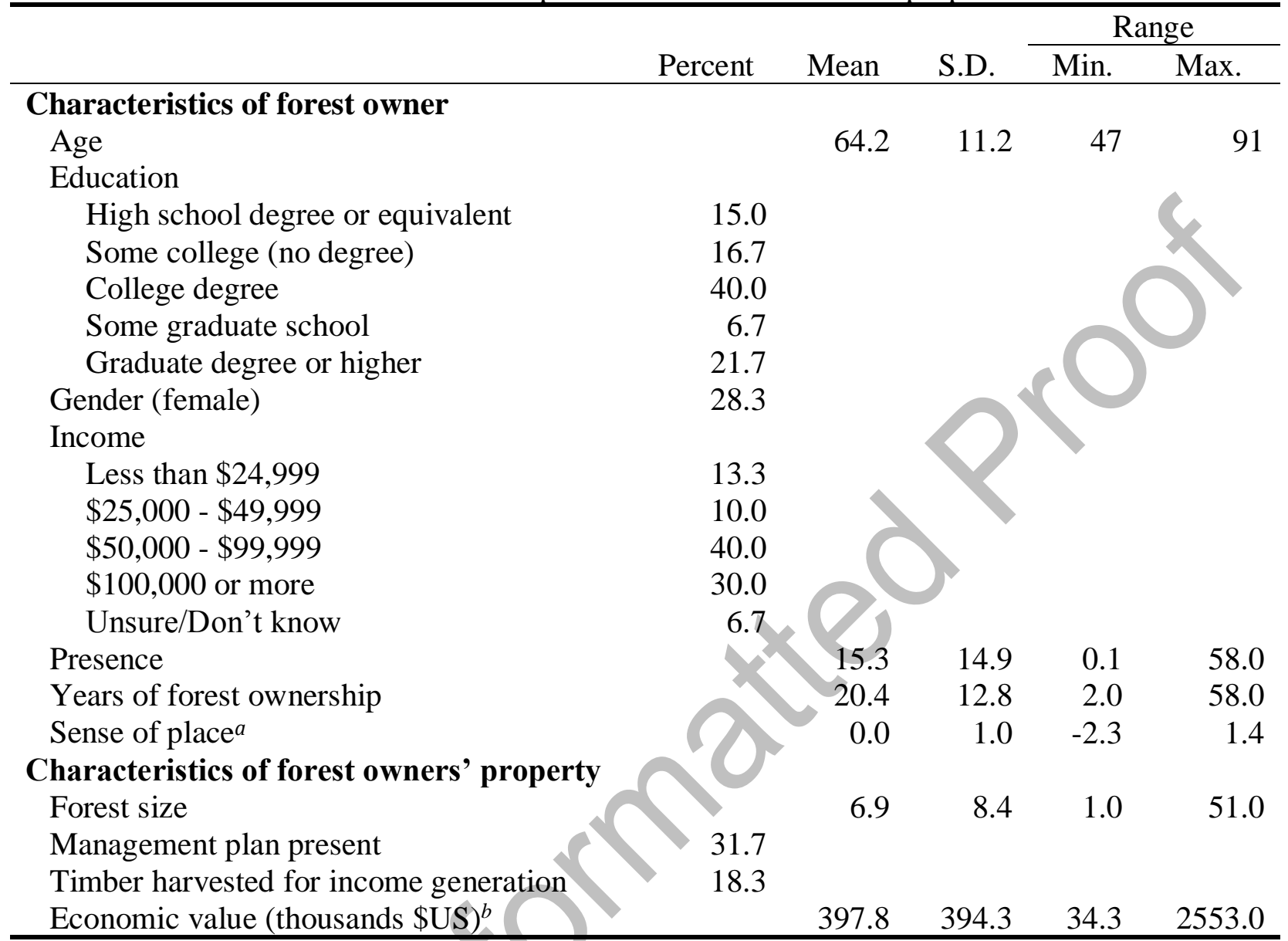

Notes. ${ }^{a}$ Factor score calculated from modified version of Jorgensen and Stedman's (2006) psychometric scale

$b$ Tax assessed value of entire parcel 
Table 3

Sampled forest owners' sense of place towards their properties

\begin{tabular}{|c|c|c|c|c|c|}
\hline \multirow[b]{2}{*}{ Sense of place statement item } & \multicolumn{5}{|c|}{ Proportion of sampled forest owners } \\
\hline & $\begin{array}{c}\text { Complete } \\
\text { disagreement }\end{array}$ & $\begin{array}{c}\text { Moderate } \\
\text { disagreement }\end{array}$ & $\begin{array}{l}\text { Neither } \\
\text { disagree nor } \\
\text { agree }\end{array}$ & $\begin{array}{l}\text { Moderate } \\
\text { agreement }\end{array}$ & $\begin{array}{l}\text { Complete } \\
\text { agreement }\end{array}$ \\
\hline $\begin{array}{l}\text { Everything about my wooded } \\
\text { land is a reflection of me }\end{array}$ & 16.7 & 16.7 & 27.8 & 13.0 & 25.9 \\
\hline $\begin{array}{l}\text { I feel that I can really be } \\
\text { myself when I am on my } \\
\text { wooded land }\end{array}$ & 8.9 & 1.8 & 28.6 & 1.9 & 13.5 \\
\hline $\begin{array}{l}\text { My wooded land reflects the } \\
\text { type of person I am }\end{array}$ & 11.1 & 14.8 & 24.1 & 27.8 & \\
\hline $\begin{array}{l}\text { I feel relaxed when I'm on my } \\
\text { wooded land }\end{array}$ & 3.5 & 7.0 & 12.3 & 28.1 & 49.1 \\
\hline $\begin{array}{l}\text { I feel happiest when I'm on } \\
\text { my wooded land }\end{array}$ & 7.1 & 8.9 & 21.4 & & 35.7 \\
\hline $\begin{array}{l}\text { My wooded land is my } \\
\text { favorite place to be }\end{array}$ & 8.9 & 10.7 & & 19.6 & 32.1 \\
\hline $\begin{array}{l}\text { I really miss my wooded land } \\
\text { when I'm way from it for } \\
\text { too long }\end{array}$ & 16.0 & 10.0 & & 20.0 & 22.0 \\
\hline $\begin{array}{l}\text { My wooded land is the best } \\
\text { place for doing the things } \\
\text { that I enjoy most }\end{array}$ & 9.3 & 18.5 & & 16.7 & 22.2 \\
\hline $\begin{array}{l}\text { For doing the things that I } \\
\text { enjoy most, no other place } \\
\text { can compare to my wooded } \\
\text { land }\end{array}$ & 16.7 & & 29.6 & 14.8 & 13.0 \\
\hline
\end{tabular}


Table 4

Results of multilevel mixed-effects logistic regression

Independent variable

\begin{tabular}{|c|c|c|c|c|c|}
\hline (fixed-effects) & Coef. & S.E. & Odds Ratio & S.E. & $p>|z|$ \\
\hline \multicolumn{6}{|l|}{ Program attributes } \\
\hline \multicolumn{6}{|l|}{ Contract length ${ }^{a}$} \\
\hline 15 -year contract & -2.266 & 0.405 & 0.104 & 0.042 & $* * *$ \\
\hline 30-year contract & -4.855 & 0.947 & 0.008 & 0.007 & $* * *$ \\
\hline \multicolumn{6}{|l|}{ Annual payment ${ }^{b}$} \\
\hline $\begin{array}{l}\$ 25 \text { per acre annual } \\
\text { payment } \\
\$ 50 \text { per acre annual }\end{array}$ & 2.917 & 0.623 & 18.492 & 11.52 & \\
\hline payment & 4.702 & 0.780 & 110.131 & & $* * *$ \\
\hline \multicolumn{5}{|l|}{ Program } & administration $^{c}$ \\
\hline \multicolumn{6}{|l|}{ Administered by a } \\
\hline \multicolumn{5}{|l|}{ Administered by a } & \\
\hline \multicolumn{6}{|c|}{ Characteristics of forest owner } \\
\hline Age & -0.059 & 0.037 & 0.943 & 0.035 & \\
\hline Education & 0.597 & 0.297 & 1.816 & 0.539 & $* *$ \\
\hline Gender & 1.136 & 0.773 & 3.115 & 2.407 & \\
\hline Income & -0.286 & 0.164 & 0.751 & 0.123 & $*$ \\
\hline Presence & -0.005 & 0.028 & 0.995 & 0.028 & \\
\hline Sense of place & -0.086 & 0.380 & 0.918 & 0.349 & \\
\hline \multicolumn{6}{|c|}{ Characteristics of forest owners' property } \\
\hline Size of forest stand & -0.030 & 0.020 & 0.971 & 0.020 & \\
\hline $\begin{array}{l}\text { Management plan } \\
\text { present }\end{array}$ & & 0.803 & 0.326 & 0.261 & \\
\hline $\begin{array}{l}\text { Timber harvested fo } \\
\text { income generation }\end{array}$ & 1.411 & 0.898 & 4.100 & 3.681 & \\
\hline Economic value & $8.97 \mathrm{e}^{-07}$ & $9.08 \mathrm{e}^{-07}$ & 1.000 & $9.08 \mathrm{e}^{-07}$ & \\
\hline Constant & -1.995 & 2.964 & 0.136 & 0.403 & \\
\hline $\begin{array}{l}\text { Random-effects } \\
\text { Parameters } \\
\text { Respondent }\end{array}$ & & & & & \\
\hline (constant) & 4.377 & 1.63 & & & \\
\hline
\end{tabular}

Notes. $n=60$ (540 discrete choices); Wald $\chi^{2}(16)=68.24 ; p>\chi^{2}<0.001 ; * * * p<0.01 ; * * p$

$<0.05 ; * p<0.10$

a 5-year contract is the base category

$b \$ 5$ per acre annual payment is the base category

${ }^{c}$ Administration by a federal agency is the base category 
Table 5. Revenue generated from payments for carbon sequestration programs relative to timber harvest and development.

\begin{tabular}{ccccrr}
\hline $\begin{array}{c}\text { Annual } \\
\text { payment } \\
\text { per acre }\end{array}$ & $\begin{array}{c}\text { Contract } \\
\text { length } \\
\text { (years) }\end{array}$ & $\begin{array}{c}\text { Average } \\
\text { discounted } \\
\text { annual } \\
\text { revenue }^{\text {a }}\end{array}$ & $\begin{array}{c}\text { Average } \\
\text { discounted } \\
\text { contract length } \\
\text { revenue }^{\mathrm{a}}\end{array}$ & $\begin{array}{c}\text { Years of } \\
\text { enrollment to } \\
\text { match timber } \\
\text { value }^{\mathrm{b}}\end{array}$ & $\begin{array}{c}\text { Years of } \\
\text { enrollment to } \\
\text { match land } \\
\text { value }^{\mathrm{c}}\end{array}$ \\
\hline$\$ 5$ & 5 & $\$ 47$ & $\$ 190$ & 493 & 8376 \\
$\$ 5$ & 15 & $\$ 30$ & $\$ 426$ & 769 & 13072 \\
$\$ 25$ & 5 & $\$ 353$ & $\$ 1,411$ & 66 & 1128 \\
$\$ 25$ & 15 & $\$ 261$ & $\$ 3,648$ & 90 & 1527 \\
$\$ 25$ & 30 & $\$ 96$ & $\$ 2,774$ & 245 & 4159 \\
$\$ 50$ & 5 & $\$ 654$ & $\$ 2,617$ & 36 & 608 \\
$\$ 50$ & 15 & $\$ 610$ & $\$ 8,540$ & 38 & 652 \\
\hline
\end{tabular}

Notes. Programs with the highest level of financial incentives ( $\$ 50$ per acre per year) were not combined with the longest contract length (30 years) in the fractional factorial design.

a Annual discount rate of 4.0\% applied (Folmer, Gabel, and Opschoor 1995).

b Mean total timber value was $\$ 23,398(S D=\$ 27,076)$. Timber value estimates derived from on-site assessments of: number and type of tree species present; average tree age; maximum diameter at breast height; and total forested area. Values were calculated only for forest owners' properties where on-site assessments were conducted $(n=41)$. This value does not include any interest the forest owner would accrue from the timber harvest.

c Mean total land value was $\$ 397,821(S D=\$ 394,287)$. 


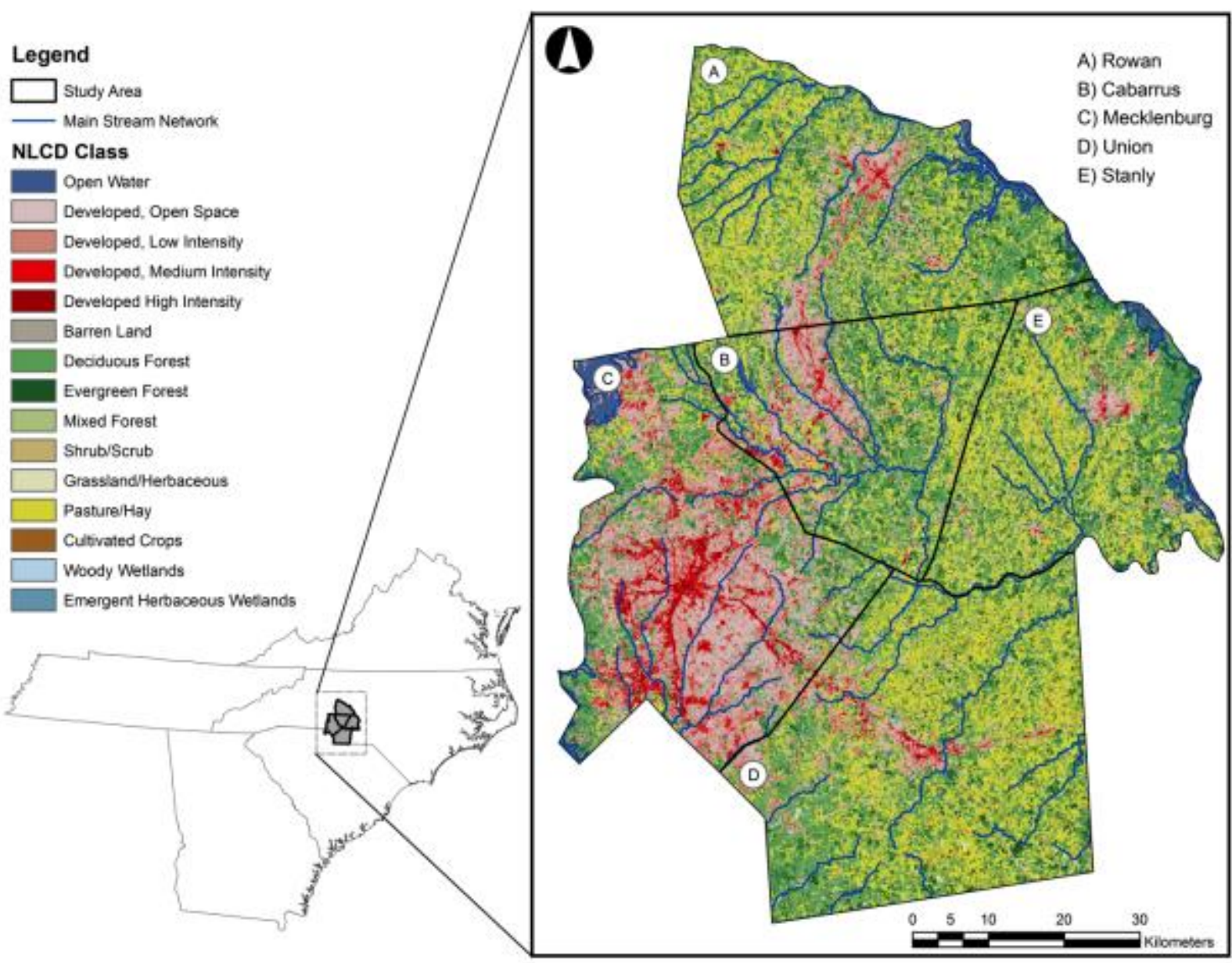

Figure 1. Study area (the counties included in the study are labeled A-E in the map inset; NLCD refers to the USDA Forest Service's National Land Cover Dataset). 


\section{Payment for Woodland Carbon Storage}

Due to increased concerns about global climate change associated with carbon emissions, programs have emerged that will pay landowners for the carbon stored by their wooded land. These programs are often aimed at forest owners since forested land removes carbon from the atmosphere and stores it in plant materials and soils. When participating in these programs, a written forest management plan is required that limits use of the wooded land for other activities and prohibits clearing of trees or participation in other payment programs for the duration of the contract. These types of 'payment for carbon storage' programs can be administered by a private company, a state agency, or a federal agency. Participation in these programs requires signing formal contracts, which vary in length from 5-30 years, in return for an annual per acre payment to the landowner.

We are interested in whether or not you would be willing to participate if such a program if it was available in your area. Please evaluate each of the following nine scenarios and indicate whether or not you would participate in the program based on those hypothetical conditions.

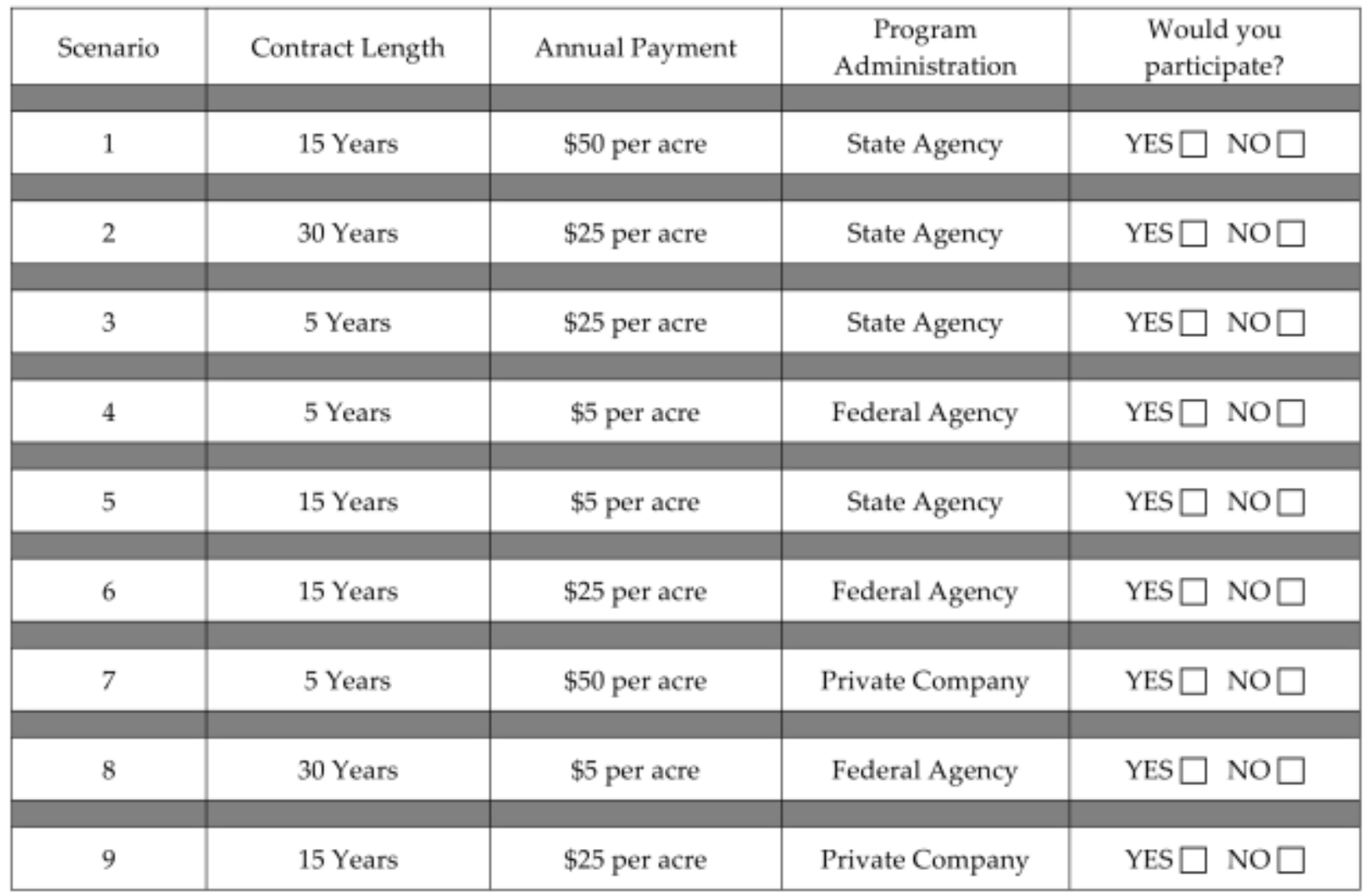

I would not participate in any of these programs

Why not?

Figure 2. Discrete choice survey question. 


\section{References}

Allan, J.D. 2004. Landscapes and riverscapes: The influence of land use on stream ecosystems. Annual Review of Ecology, Evolution, and Systematics 35: 257-84.

Banzhaf, M.R., F.R. Johnson, and K.E. Mathews. 2001. Opt-out alternatives and anglers' stated preferences. P. 157-177 in The choice modelling approach to environmental valuation, Bennett, J., and R. Blamey (eds.). Edward Elgar Publishing Limited, Cheltenham, United Kingdom.

BenDor, T., D.A. Shoemaker, J.-C. Thill, M.A. Dorning, and R.K. Meentemeyer. 2014. A mixed-methods analysis of social-ecological feedbacks between urbanization and forest persistence. Ecology \& Society 19 (3): 3.

Bengston, D.N., S.T. Asah, and B.J. Butler. 2010. The diverse values and motivations of family forest owners in the United States: An analysis of an open-ended question in the National Woodland Owner Survey. Small-Scale Forestry 10 (3): 339-55.

Bengston, D.N., J.O. Fletcher, and K.C. Nelson. 2004. Public policies for managing urban growth and protecting open space: Policy instruments and lessons learned in the United States. Landscape and Urban Planning 69 (2-3): 271-86.

Bigsby, H. 2009. Carbon banking: Creating flexibility for forest owners. Forest Ecology and Management 257 (1): 378-83.

Bliss, J.C., and A.J. Martin. 1989. Identifying NIPF management motivations with qualitative methods. Forest Science 35 (2): 601-22.

Butler, B.J. 2008. Family forest owners of the United States, 2006. USDA Forest Service General Technical Report NRS-27.

Carmines, E.G., and J.P. McIver. 1981. Analyzing models with unobserved variables: Analysis of covariance structures. P. 65-116 in Social measurement: Current issues, Bohrnstedt, G.W., and E.F. Borgatta (eds.). Sage, Beverly Hills, CA.

Center for Climate and Energy Solutions. 2016. Multi-state climate initiatives. Available online at www.c2es.org/us-states-regions/regional-climate-initiatives; last accessed Sept. 27, 2016.

Climate Policy Initiative. 2016. California carbon dashboard. Available online at www.calcarbondash.org; last accessed Sept. 27, 2016.

Creighton, J., K.A. Blatner, and M.S. Carroll. 2015. For the love of the land: Generational land transfer and the future of family forests in western Washington State, USA. Small-Scale Forestry, 1-15.

Derissen, S., and U. Latacz-Lohmann. 2013. What are PES? A review of definitions and an extension. Ecosystem Services 6: 12-15. 
DeShazo, J.R., and G. Fermo. 2002. Designing choice sets for stated preference methods: The effects of complexity on choice consistency. Journal of Environmental Economics and Management 44 (1): 123-43.

Dickinson, B.J., T.H. Stevens, M.M. Lindsay, and D.B. Kittredge. 2012. Estimated participation in U.S. carbon sequestration programs: A study of NIPF landowners in Massachusetts. Journal of Forest Economics 18 (1): 36-46.

Dillman, D.A., J.D. Smyth, and L.M. Christian. 2008. Internet, mail, and mixed-mode surveys: The tailored design method (3rd ed.). Wiley, New York.

Dorning, M.A., J. Koch, D.A. Shoemaker, and R.K. Meentemeyer. 2015. Simulating urbanization scenarios reveals tradeoffs between conservation planning strategies. Landscape and Urban Planning 136 (April): 28-39.

Dorning, M.A., J.W. Smith, D.A. Shoemaker, and R.K. Meentemeyer. 2015. Changing decisions in a changing landscape: How might forest owners in an urbanizing region respond to emerging bioenergy markets?" Land Use Policy 49 (December): 1-10.

Engel, S., S. Pagiola, and S. Wunder. 2008. Designing payments for environmental services in theory and practice: An overview of the issues. Ecological Economics 65 (4): 663-74.

Ferraro, P.J., and S.K. Pattanayak. 2006. Money for nothing? A call for empirical evaluation of biodiversity conservation investments. PLoS Biology 4 (4): e105.

Finley, A.O., and D.B. Kittredge. 2006. Thoreau, Muir, and Jane Doe: Different types of private forest owners need different kinds of forest management. Northern Journal of Applied Forestry 23 (1): $27-34$.

Fletcher, L.S., D. Kittredge, and T. Stevens. 2009. Forest landowners' willingness to sell carbon credits: A pilot study. Northern Journal of Applied Forestry 26 (1): 35-37.

Folmer, H., H.L. Gabel, and H. Opschoor. 1995. Principles of environmental and resource economics. Edward Elgar, Aldershot, United Kingdom.

Gobster,P.H., S.I. Stewart, and D.N. Bengston. 2004. The social aspects of landscape change: Protecting open space under the pressure of development. Landscape and Urban Planning 69 (2-3):149-51.

Gordon, J.S., A. Barton, and K. Adams. 2013. An exploration of African American forest landowners in Mississippi. Rural Sociology 78 (4): 473-97.

Hair, J.F., W.C. Black, B.J. Babin, and R.E. Anderson. 2009. Multivariate data analysis (7 ${ }^{\text {th }}$ ed.). Prentice Hall. 
Hanley, N., S. Mourato, and R.E. Wright. 2001. Choice modelling approaches: A superior alternative for environmental valuation? Journal of Economic Surveys 15 (3): 435-62.

Hansen, A.J., R.L. Knight, J.M. Marzluff, S. Powell, K. Brown, P.H. Gude, and K. Jones. 2005. Effects of exurban development on biodiversity: Patterns, mechanisms, and research needs. Ecological Applications 15 (6): 1893-1905.

Hensher, D.A. 2006. How do respondents process stated choice experiments? Attribute consideration under varying information load. Journal of Applied Econometrics 21 (6): 861-78.

Hensher, D.A., and W.H. Greene. 2002. The mixed logit model: The state of practice. Working Paper ITS-WP-02-01.

Interagency Working Group on the Social Cost of Carbon. 2013. Technical update of the social cost of carbon for regulatory impact analysis under Executive Order 12866 (Technical support document). Interagency Working Group on the Social Cost of Carbon.

Jack, B.K., C. Kousky, and K.R.E. Sims. 2008. Designing payments for ecosystem services: Lessons from previous experience with incentive-based mechanisms. Proceedings of the National Academy of Sciences 105 (28): 9465-70.

Jorgensen, B.S., and R.C. Stedman. 2006. A comparative analysis of predictors of sense of place dimensions: Attachment to, dependence on, and identification with lakeshore properties. Journal of Environmental Management 79 (3): 316-27.

Kelly, M.C., R.H. Germain, and S.V. Stehman. 2015. Family forest owner preferences for forest conservation programs: A New York case study. Forest Science 61 (3): 597-603.

Khanal, P.N., D.L. Grebner, I.A. Munn, S.C. Grado, R.K. Grala, J.E. Henderson, and M.K. Measells. 2016. Nonindustrial private forest landowner beliefs toward climate change and carbon sequestration in the southern United States. Journal of Forestry 114.

Kilgore, M.A., J.L. Greene, M.G. Jacobson, T.J. Straka, and S.E. Daniels. 2007. The influence of financial incentive programs in promoting sustainable forestry on the nation's family forests. Journal of Forestry 105 (4): 184-91.

Knoot, T.G., M. Rickenbach, and K. Silbernagel. 2015. Payments for ecosystem services: Will a new hook net more active family forest owners? Journal of Forestry 113 (2): 210-18.

Kontoleon, A., and M. Yabe. 2003. Assessing the impacts of alternative 'opt-out' formats in choice experiment studies: Consumer preferences for genetically modified content and production information in food." Journal of Agricultural Policy and Resources 5 (1): 1-43.

Lai, P.-H., and U.P. Kreuter. 2012. Examining the direct and indirect effects of environmental change and place attachment on land management decisions in the Hill Country of Texas, USA. Landscape and Urban Planning 104 (3-4): 320-28. 
Lippke, B., and J. Perez-Garcia. 2008. Will either cap and trade or a carbon emissions tax be effective in monetizing carbon as an ecosystem service. Forest Ecology and Management 256 (12): 2160-65.

Lokocz, E., R.L. Ryan, and A.J. Sadler. 2011. Motivations for land protection and stewardship: Exploring place attachment and rural landscape character in Massachusetts. Landscape and Urban Planning 99 (2): 65-76.

Markowski-Lindsay, M., T. Stevens, D.B. Kittredge, B.J. Butler, P. Catanzaro, and B.J. Dickinson. 2011. Barriers to Massachusetts forest landowner participation in carbon markets. Ecological Economics 71 (November): 180-90.

McFadden, D. 1973. Conditional logit analysis of qualitative choice behavior. P. 101-108 in Frontiers in econometrics, Zarembka, P. (ed.). Academic Press, New York.

- 1984. Econometric analysis of qualitative response models. P. 1396-1457 in Handbook of econometrics, Griliches, Z., and M. Intriligator (ed.). North-Holland, Amsterdam, Netherlands.

McFadden, D., and K. Train. 2000. Mixed MNL models for discrete response. Journal of Applied Econometrics 15: 447-70.

Meentemeyer, R.K., W. Tang, M.A. Dorning, J.B. Vogler, N.J. Cunniffe, and D.A. Shoemaker. 2013. FUTURES: Multilevel simulations of emerging urban-rural landscape structure using a stochastic patch-growing algorithm. Annals of the Association of American Geographers 103 (4): 785-807.

Metz, D., and L. Weigel. 2010. Key findings from recent national opinion research on 'ecosystem services.' The Nature Conservancy, Missoula, MT.

Millennium Ecosystem Assessment. 2003. Ecosystems and human well-being: A framework for assessment. Island Press, Washington, DC.

Miller, K.A., S.A. Snyder, and M.A. Kilgore. 2012. An assessment of forest landowner interest in selling forest carbon credits in the lake states, USA. Forest Policy and Economics 25 (December): 113-22.

Miller, K.A., S.A. Snyder, M.A. Kilgore, and M.A. Davenport. 2014. Family forest landowners' interest in forest carbon offset programs: Focus group findings from the lake states, USA. Environmental Management 54 (6): 1399-1411.

Moore, F.C., and D.B. Diaz. 2015. Temperature impacts on economic growth warrant stringent mitigation policy. Nature Climate Change 5 (2): 127-31. 
Muradian, R., M. Arsel, L. Pellegrini, F. Adaman, B. Aguilar, B. Agarwal, E. Corbera, et al. 2013. Payments for ecosystem services and the fatal attraction of win-win solutions.

Conservation Letters 6 (4): 274-79.

Muradian, R., E. Corbera, U. Pascual, N. Kosoy, and P.H. May. 2010. Reconciling theory and practice: An alternative conceptual framework for understanding payments for environmental services. Ecological Economics 69 (6): 1202-8.

Naidoo, R., and W. Adamowicz. 2005. Economic benefits of biodiversity exceed costs of conservation at an African rainforest reserve. Proceedings of the National Academy of Sciences 102 (46): 16712-16.

Newburn, D., S. Reed, P. Berck, and A. Merenlender. 2005. Economics and land-use change in prioritizing private land conservation. Conservation Biology 19 (5): 1411-20.

Newell, R.G., W.A. Pizer, and D. Raimi. 2013. Carbon markets 15 years after Kyoto: Lessons learned, new challenges. The Journal of Economic Perspectives 27(1): 123-46.

Nielsen-Pincus, M., R.G. Ribe, and B.R. Johnson. 2015. Spatially and socially segmenting private landowner motivations, properties, and management: A typology for the wildland urban interface. Landscape and Urban Planning 137 (May): 1-12.

North Carolina Department of Revenue. 2015. Present-use value program guide. North Carolina Department of Revenue, Raleigh, NC.

Nunnally, J., and I. Bernstein. 1994. Psychometric theory (3rd ed.). McGraw-Hill Humanities/Social Sciences/Languages.

Paul, M.J., and J.L. Meyer. 2001. Streams in the urban landscape. Annual Review of Ecology and Systematics 32: 333-65.

Png, I. 2012. Managerial economics ( $4^{\text {th }}$ ed.). Blackwell, Oxon, United Kingdom.

Rabotyagov, S.S., and S. Lin. 2013. Small forest landowner preferences for working forest conservation contract attributes: A case of Washington State, USA. Journal of Forest Economics 19 (3): $307-30$.

Salzman, J. 2005. Creating markets for ecosystem services: Notes from the field. New York University Law Review 80: 870.

Shelley, B.G. 2011. What should we call instruments commonly known as payments for environmental services? A review of the literature and a proposal. Annals of the New York Academy of Sciences 1219: 209-25. 
Singh, K.K., J.B. Vogler, D.A. Shoemaker, and R.K. Meentemeyer. 2012. LiDAR-Landsat data fusion for large-area assessment of urban land cover: Balancing spatial resolution, data volume and mapping accuracy. ISPRS Journal of Photogrammetry and Remote Sensing 74: 110-21.

StataCorp. 2015. [ME] Meqrlogit. P. 110-25 in Stata: Release 14. StataCorp LP, College Station, TX. Available online at: www.stata.com/manuals14/memelogit.pdf; last accessed Sep. 27, 2016.

Stedman, R.C. 2002. Toward a social psychology of place: Predicting behavior from place-based cognitions, attitude, and identity. Environment and Behavior 34 (5): 561-81.

Tarrant, M.A., H.K. Cordell, and G.T. Green. 2003. PVF: A scale to measure public values of forests. Journal of Forestry 101 (6): 24-30.

Terando, A.J., J. Costanza, C. Belyea, R.R. Dunn, A. McKerrow, and J.A. Collazo. 2014. The southern megalopolis: Using the past to predict the future of urban sprawl in the southeast U.S. PLoS ONE 9 (7): e102261.

Theobald, D.M. 2001. Land-use dynamics beyond the American urban fringe. Geographical Review 91 (3): 544-64.

- 2005. Landscape patterns of exurban growth in the USA from 1980 to 2020. Ecology and Society 10 (1): 32.

Theobald, D.M., J.R. Miller, and N.T. Hobbs. 1997. Estimating the cumulative effects of development on wildlife habitat. Landscape and Urban Planning 39 (1): 25-36.

Theobald, D.M., and W.H. Romme. 2007. Expansion of the US wildland-urban interface. Landscape and Urban Planning 83 (4): 340-54.

Thompson, D.W., and E.N. Hansen. 2012. Factors affecting the attitudes of nonindustrial private forest landowners regarding carbon sequestration and trading. Journal of Forestry 110 (3): 12937.

2013. Carbon storage on non-industrial private forestland: An application of the theory of planned behavior. Small-Scale Forestry 12 (4): 631-57.

Train, K.E. 2009. Discrete choice methods with simulation (2nd ed.). Cambridge University Press, Cambridge, United Kingdom.

Wade, D., and C. Moseley. 2011. Foresters' perceptions of family forest owner willingness to participate in forest carbon markets. Northern Journal of Applied Forestry 28 (4): 199-203. 